\title{
Research on development issues of rural banks
}

\author{
Xiaohong Zou \\ Fuzhou University of International Studies and Trade, Fuzhou City, Fujian Province, China
}

Key words: rural banks, rural finance, development.

\begin{abstract}
After years of policy support and market promotion, a new-type rural financial system with diversified levels and wide coverage is gradually being established in China. China is now fully implementing the national strategy for targeted poverty alleviation, quickening poverty alleviation of countryside as soon as possible. Poverty alleviation and wealthy of rural population is inseparable from development of new agricultural and construction of new rural, realization of these objectives can not be separated from effective financial support undoubtedly. As new-type of rural financial institutions that based on agriculture and rooted in grass-root, Chinese rural banks have important role in supporting rural construction and promoting effective implementation of targeted poverty alleviation and function greatly. This paper firstly analyzes development status of rural banks, and then analyzes problems it faces, finally, provides kind of ideas on future development path of rural banks.
\end{abstract}

\section{Developing status of rural banks}

In the past ten years, if rural banks are compared with BOC, ABC, ICBC, CCB, BOCOM and other major state-owned banks as well as other local banks, they have always been marginalized. Encouraged by the Central Government's efforts to promote the construction of new countryside, and implementation of the national strategy for targeted poverty alleviation, rural banks that have not received sufficient attention before are now steadily rising in rural financial markets. The reason for its rising and increased exposure is not just because of policy boost, it's more because Chinese rural banks have gradually found positions that fit their own development needs after experiencing downturn and precipitation, in other words, only base on countryside and root in grass-root could rural banks go along healthy development paths.

\section{Problems in development of rural banks}

In the process of new rural construction, it is of particular importance to develop rural banks greatly, as well as increase micro and low guarantee credit. In other words, only by adjusting policies, exploiting market, broadening ideas, putting development of rural banks on the table, and making use of testing, practice, strive to develop, summary and analysis, self-healing and improvement, could eventually by means of developing rural banks to make a legal, normative, inclusive rural financial industry in China, thus to realize new rural construction of China, and put the final goal for targeted poverty alleviation into practice. However, although rural banks of China develop 
rapidly, some problems still exist. The paper combines development situation of Chinese rural banks at present, focusing on some newly emerged problem in actual operating process of Chinese rural banks, to summarize the followings.

\subsection{Higher market access system}

When it comes to defect, the first and foremost is the access system of Chinese rural banks. There is no doubt that access system is the base of rural banks. According to Provisional Regulations for Management of Rural Banks, rural banks established in a county (city) shall have a registered capital no less than 3 million Yuan; rural banks established in a village (town) shall have a registered capital no less than 1 million Yuan. The cost seems to be low, however, shareholdings of individual natural person shareholders, total shareholdings of a single non-bank financial institution or single non-financial institution corporate entity and all its related parties shall less than $10 \%$ of the total share capitals. It is because of such regulations that no matter how much owners of non-bank financial institutions and enormous private capital want to enter financial market, they could not get rid of the failed result. Such policies result a higher market access barriers for rural bank, which restrains development of rural banks to some extent.

\subsection{Lower profitability}

Due to special positioning of rural banks, its customers are doomed to be framers and micro companies. Limit of credit loans of Chinese rural banks currently are mostly between 20 thousand Yuan and 100 thousand Yuan; for micro loans below 20 thousand Yuan, rural banks only need to decide whether to grant the loan basing on the expected output value and credit status of a farmer, no physical mortgage is needed, furthermore, term and rate of the loan will be more flexible in comparison with ordinary commercial loans. It is this kind of loans that brings benefits to farmers and private entrepreneurs simultaneously, have its profitability restrained.

\subsection{Lower market competitiveness}

In comparison with other commercial banks, rural bank is just a starting and developing financial institution. Among rural residents, private entrepreneurs with strong capital strength are generally stable customers of BOC, ABC, ICBC, CCB, BOCOM and other major state-owned banks or medium local commercial banks. And the real low-end customers have fewer financial demands. Besides, with constant perfection of systems, developing environment turns better, more and more commercial credit companies and financial management institutions begin to enter the financial blue ocean to take a share. The increasingly fierce market competition is a first issue that rural banks must face in their future development.

\subsection{Insufficient policy supporting}

The original intention for establishment of rural banks it to complete rural and urban financial service, making economic development of countryside more convenient, fast and effective. This is not only a market behavior, but also a social responsibility overriding its commercial nature. However, rural banks actually don't get sufficient support on existing policy preferences; at least, they don't get the same treatment as rural credit cooperatives. In the aspect of taxation, rural banks and other commercial banks are on a same level. However, rural credit cooperatives not only enjoy a very favorable policy system in taxation, but will also be interest compensated correspondingly by financial department of governments when issuing agricultural loans at rural credit cooperatives. As time passes, for their own development, rural banks are bound to choose a way that could be 
continued, i.e. the way to abandon farming and transfer to commerce.

\section{Measures to promote development of rural banks}

\subsection{Innovate new models for establishment of rural banks}

During the process of large scale promotion of rural banks, conditions for market access system are excessively harsh, which restrains development process of rural banks to some extent. However, as banking industry faced risks are extremely special, and risk supervision capacities of Chinese financial industry and banking industry are very limited, so establishing conditions for rural banks is hard to loosen by governments in a short term. Nevertheless, only by turning rural banks to be certain scales, and establishing rural banks in large quantities, will it be more benefit to change the current status. Furthermore, how to judge development directions of rural banks according to local conditions, innovate new models for establishment of rural banks and promote them will cost a lengthy practicing period and observing period.

\subsection{Improve the profitability of rural banks}

As mentioned before, original intention for establishment of rural banks are greatly different from those of other ordinary commercial banks. However, as a bank, major contradictions exist between agricultural benefiting of a rural bank and its commercial nature. Therefore, the next goal of rural banks will be certainly to find a unique balance to maintain self-profitability and serve large numbers of rural residents, only by this way, could micro credit and low mortgage loan be continued, at the same time of exploiting new market and developing own customers, to assume social responsibility better.

\subsection{Strength cooperation with financial industry}

Positioning of rural banks is extremely special. It is obviously that they don't have the opportunity to compete with other financial institutions with their current strength. So, developing path of rural banks must always keep cooperating with other financial institutions, seeking for common interests. E.g. rural banks could cooperate with major commercial banks and credit companies actively, which will not only lose no customer, but also spread risk effectively. Furthermore, during the development process of rural banks, it is necessary for them to learn from experience of other financial institutions, also learn from mistakes and reflect on their own inadequacies, thus to enable themselves to keep growing through cooperation in fierce competition. Meanwhile, rural banks should also make use of economic development characteristics where they are located, to make targeted product innovations and try to exceed their cooperative opponents, as well as obtain the ability to confront other financial institutions as early as possible.

\subsection{Strengthen policy supporting}

In comparison with previous points, strengthen policy supporting can be said to be top priority for the development of rural banks.

Firstly, interest rate subsidy for loans of rural banks should be given by our government, making rural banks enjoy a same preferential tax policy with rural credit cooperatives. Secondly, risk compensation to rural banks issued farming related loans should also be made. Thirdly, reduce operational cost of rural banks provided farming related loans. By strengthening policy supporting, to make rural banks enjoy a same treatment with rural credit cooperatives at present eventually, enabling them to find a balance between "profitability" and "inclusive”, and implementing the 
philosophy for "base on rural, aim to benefit the people”.

\section{Conclusions}

China's national conditions are very special, there are more than 600 million farmers and GDP per capita ranks lower in the world rankings; it is up to now still a country with traditional farming as livelihood. Be it is the high cost eastern coastal area, or sparsely populated western regions, for financial network currently, most countryside could not be fully covered by rural banks. This will not be conducive to new countryside proposals for socialist modernization, which also restrains effective implementation of the nation strategy for targeted poverty alleviations indirectly. Therefore, active promotion of rural banks is an important task for China's rural financial layout in the new era.

\section{References}

[1] Gao Xiaoyan. Research on sustainable development of rural banks in China [J]. Research on Financial and Economic Issues, 2011(6).

[2] Zhao Zhigang. The development difficulties and policy suggestions of rural banks in China [J]. New Finance, 2011(1).

[3] Li Ying. Research on the development issues of rural banks in China [J]. Chinese Agricultural Science Bulletin, 2013(6).

[4] Jin Hao. The current situation and problems analysis of operation and development of Chinese rural banks [J]. Rural Finance Research 2014(4).

[5] Xin Bensheng. Development status and prospects of rural banks [J]. New Finance, 2011(5).

[6] Zhang Yongliang. Review and reconstruction of the market access legal system for rural banks [J]. Law Business Research, 2017(2). 